\title{
Using the Social Network for Business Sustainability: Examining Start-up SME Firms in Malaysia
}

\author{
Ehsan Fansuree Surin, Ismail Ab. Wahab, Mohd. Hazman Fitri Hussin, \\ Mohd. Najib Saad, Mior Harris Mior Harun \\ Universiti Teknologi MARA, Selangor, Malaysia \\ efansuree@salam.uitm.edu.my
}

\begin{abstract}
The purpose of this paper is to examine social network among SME firms in Malaysia. Specifically, this paper aims to investigate the usage of social network among Malay ethnic entrepreneurs in the start-up phase of SME firms in manufacturing sectors. Secondly, this paper aims to investigate the relationship between social network and business performance of the start-up manufacturing SME firms in Malaysia. The research data were collected through self-administered and mail questionnaire with a stratified random sample of 83 SME firms around Malaysia. The hierarchical regression was used for hypothesis testing. The result shows that Malay entrepreneurs used extensively business contact in their social network. For the hypothesis testing, the hierarchical regression shows that social network has significantly positive relationship with business performance. This paper contributes to the body of knowledge especially to the social network theme in Malaysia which is considered to be in the infant stage still. The discussions of the results, the contribution to the body of knowledge as well as limitations of the study are also discussed.
\end{abstract}

Keyword: Social network, Start-up phase, SMEs, Malay entrepreneurs, Malaysia

\section{Introduction}

Social network is defined as the interrelationship between the entrepreneurs (ego) and their contacts (alter/s) for business development purposes (Formbrun, 1982). The concept of network and its focus lies on the person who has the relationship with ego and thus, social network research utilises the relationship either directly or indirectly between the ego and their alter(s). Alters comprise family members, friends, relatives and business contacts (Birley, 1985; Brown and Butler, 1995; Das and Teng, 1997; Premaratne, 2001). The need for social network was cited by the scholars to secure important resources from the alters especially for the start-up firms (Witt, 2004; Witt, Schroeder and Merz, 2008). Even though the research on social network theme was done extensively, there is a limited understanding on the role of social network especially in the developing country like Malaysia (Minai, Ibrahim and Kheng, 2012; Surin and Wahab, 2013). Majority of the researches were done in the western countries for example in the Scandinavia (eg. Greve, 1995; Nybakk, Lunnan, Jenssen and Crespell, 2013; Nybakk, Vennesland, Hansen and Lunnan, 2008), in the United Kingdom (eg. Cromie and Birley, 1992; Kenny and Fahy, 2011; Ostgaard and Birley, 1996) and in the United State of America (eg. Martinez and Aldrich, 2011; Quan and Motoyama, 2010; Zimmerman, Barsky and Brouthers, 2009). Thus, this paper was carried out to examine social network among manufacturing SMEs in Malaysia during their start-up phase. Specifically, this study attempts to examine; (1) the usage of social network of Malay manufacturing SME firms, (2) the relationship between social network and business performance of Malay manufacturing SME firms. Malay entrepreneurs are included in the analysis as this ethnic constitutes as one of the major ethnic players in the entrepreneurship field in Malaysia. The remainder of this paper is organized as follows. We introduce social network theory and the development of the hypothesis in Section 2. The research methodology comprises of sample and data collection method as well as operationalisation of variables used in this study is presented in Section 3. In Section 4, we present the research findings including descriptive analyses, reliability test, mean, standard deviation and correlation and also the hypothesis testing. In the discussion section (Section 5), we present the adoption of the alters in the entrepreneurs' social network and discuss how finding reflects on prior investigation. We also put forward the contributions and limitations of the study in Section 6. 


\section{Literature Review}

Social Network Theory: The social network theory was popularized in the middle of the 1980s by Birley (1985) and sought to explain the capability of the network to help the entrepreneur access resources. A social network is made up of persons to whom the individual primarily relates to on a social level. This network functions largely on trust (Porras, Clegg and Crawford, 2004). Firms' survival in the business is dependent on the resources obtained by the entrepreneurs. The core argument of this theory is entrepreneurs will fulfill their firm's demands through alters due to the lack of certain resources. Due to the resource constraint, the entrepreneurs have searching for the alters to obtain an assistance through social network (Starr and MacMillan, 1990). The resources mentioned could take the form of information, motivational resources and material resources (Jenssen and Koenig, 2002). Social network adopted the structuralist perspective when operationalising and measuring network and try to connect the theme with organizational outcomes (Borgatti and Foster, 2003; Hoang and Antoncic, 2003). Structuralist perspectives explain the configuration of network ties of the social network. The network is structured within which the entrepreneurs and the alters interact. It also provides an understanding of the role of network structures in influencing entrepreneurial outcomes. The perspectives included in this study are network density and network centrality. Network density can be defined as alters that are connected and know each other in the network of the ego (Hansen, 1995). The density of a network forms part of the network characteristic and also identifies the number of ties that link the ego to the alters (Rowley, 1997; Frazier, 2000). Ibarra (1995) introduced the term homophily in social network that refers to the tendency of individuals to bond with others who are similar. For example, Ibarra found that a group of people bonded as they shared a similarity in terms of sex. Some of the barriers faced in a dense network are communication problems where different languages are spoken, a lack of familiarity between the alters and the uncertain purpose of participating in the group. People who share a common understanding maybe included in the dense network. From the ego's perspective, a dense network that functions on trust will enable them to acquire resources easily. Previous studies discovered the network density positively affects firm's business performance (Liedka, 1991). Reese (1992) also concluded that network density may contribute to the business performance.

On the other hand, network centrality refers to the position of the ego in the group from which the flow of information is spread (Frazier, 2000). In business, an ego that is central to communication will have early access to information and thus control the spread of information to the alters. Centrality is key to controlling the flow of information from multiple sources (Rowley, 1997) and also essential in controlling the distribution of resources (Boje and Whetten, 1981). However, in large network, not all information will be transferred evenly to the alters. Therefore, it is necessary to place oneself centrally in the network in order to access information and control the transfer of information. Individuals can still be associated with others even though they are not in the same area or field (Perry-Smith, 2006). Centrality is beneficial to motivate the individual's innovation effort (Ibarra, 1993), allow learning and knowledge transfer (Cantner and Joel, 2011), business unit's innovation enhancement (Tsai, 2001) and also beneficial to the ego as they are able to influence resource transactions among the social network members (Perry-Smith, 2006). In this paper, we propose positive relationship between social network and business performance as suggested by social network theory (Hoang and Antoncic, 2003). The positive relationship was developed to indicate the direction for the hypothesis testing. It had been adopted by prior researchers (Brown and Butler, 1995; Bruderl and Preisendorfer, 1998; Greve, 1995; Quan and Motoyama, 2010). Therefore, the hypothesis is;

$\mathrm{H}_{1}$ There is a positive and significant relationship between social network and business performance

\section{Methodology}

Sample and data collection method: Our unit of analysis is organization; therefore the data were collected from the SMEs owner-managers. In Malaysia, the entrepreneur can be viewed simply as an owner-manager because both these roles are significant to the business (Ndubisi and Kahraman, 2005). A total of 306 firms were selected by using stratified random sampling (the firms were categorised according to their geographical zones; North, South, East, Central and West). The listing was obtained from Companies Commission of Malaysia (SSM) based on the criteria of being a manufacturing SME; which have either of the 
following; (1) more than 5 and fewer than 150 full-time employees and (2) an annual sales turnover between RM250,000 and less than RM25 million. Additional criteria were also used in sample selection; (1) the full name of the owner has been stated in the directory, (2) the firm must been operating not more than three years, and (3) the firm is not a franchise-based. This is due to the lack of control over their business and tailored to the requirement of their parent company. This study utilized mailed questionnaire and self administered questionnaire to obtain data from the sample firms in Malaysia. Questionnaire is found to be predominant research method used in social network-based research (Greve, 1995; Greve and Salaff, 2003; Marsden, 1990). 83 completed questionnaires were received, yielding a response rate of 8.3 percent (1000 questionnaires sent). Another 5 responses were considered inappropriate as they did not meet the SMEs criteria and provided incomplete information for the name generator. The questionnaires sent out especially to food and beverage entrepreneurs were attached with official receipts and packaging of the entrepreneurs' brands to demonstrate researcher support. The initiative was conducted in order to increase the response rate.

Operationalisation of Variables: In order to determine social network, the entrepreneurs were asked to list down five names of alters they had been in contact with over the last month. In general, respondents are usually required to name five important alters that they interact with whilst running the business (Greve, 1995; Hansen, 1995; Marsden, 1990). Based on the name listed by entrepreneurs, they are then asked to rate how familiar each alter is with other members in the network (network density). The respondents were then asked to rate the items using 5 points Likert scale where 1 point meant that they strongly disagreed whilst 5 points signified that they strongly agreed. These answers would thus uncover strong links where alters knew each other well and weak links where alters were mere acquaintances. For another measure, network centrality was measured by using six items using a 5 points Likert scale. 1 point meant that they strongly disagreed whilst 5 points signified that they strongly agreed. For the business performance measure, the modified non-financial business performance items were adopted from Lee and Lee (2007) and Lee, Lee and $\mathrm{Wu}$ (2010). The items were rated using the 5 points Likert scale. In this scale, 5 points signify strong agreement whilst 1 point shows that the entrepreneurs strongly disagreed. This study employed nonfinancial measure to analyze business performance. Procuring financial data directly from the SME entrepreneurs may lead to false information due to the sensitive nature of the data (Mahmood and Hanafi, 2013; Wahab, 1996). Therefore, utilising subjective measures are acceptable when the nature of the data is sensitive which may lead to inaccurate reporting by entrepreneurs (Ahmad, 2007). Lastly, we controlled the potential bias towards business performance. The control variables include firm size, firm age and parental business history.

\section{Findings}

Descriptive Statistics: The findings showed that the majority of the respondents were male accounting for 51.8 percent of the sample, whereas females accounted for 48.2 percent of respondents. The age of the respondents showed that most of them were 46 years old and above (39.8\%). Only 7.2 percent 26 to 30 years of age, meanwhile no respondent comes from 25 years and below. In terms of educational level, the majority of the respondents obtained the SPM (31.3\%). This is followed by diploma holders $(25.3 \%)$, undergraduate degree (22.9\%), STPM (4.8\%), master's degree (3.6\%), and Ph.D (1.2\%). Approximately 7 percent of respondents reported no formal educational. The majority of respondents (37.3\%) possessed 11 to 15 years of work experience. This is followed by 31.1 percent of respondents who had 16 to 20 years of work experience and 26.5 percent with 5 to 10 years of work experience. A small number of respondents represented the maximum years of work experience with 4.8 percent having more than 20 years of working experience. No respondents indicated less than 5 years of working experience. In terms of firm's profile, the majority of businesses (54) came from the food and beverage sector, wood-based product (11), textiles, apparel and leather (5), electric and electronics (3), plastic-based products (2) and rubber-based products (1) and approximately 7 of the respondents indicated their firms were in other sectors, representing a combination of businesses in wood, iron and metal-based sectors. As regards business types, soleproprietorship firms accounted for 48.2 percent of enterprises, and 27.7 of enterprises reported soleproprietorship while another 24.1 percent of enterprises were private-limited firms. In terms of firm's location, most of the firms operated in Western region (29), followed by Southern region (26), Northern 
region (15), Central region (11) and Eastern region (2). Through the name generator method, majority of the respondents indicates that business contacts are the main player in their social network which constitutes 156 persons. This is followed by family members (135) and friends (89). Only a small number of relatives (35) were included in the entrepreneurs' social network.

Reliability Test: For this study, the reliability test was conducted on each variable to ensure their reliability and internal consistency. The Cronbach's alpha value were considered good since all the reliability values were above 0.70 , which concur with Nunnally's (1978) minimum threshold of 0.70 . The results of reliability test are presented in Table 1.

Table 1: Cronbach alpha values for variables

\begin{tabular}{lll}
\hline Study variables & Items & Cronbach alpha \\
\hline 1. Social network & & \\
- Network density & 3 & 0.750 \\
- Network centrality & 6 & 0.749 \\
2. Business performance & 6 & 0.771 \\
\hline
\end{tabular}

Mean, Standard Deviation and Correlation: Table 2 illustrates mean, standard deviation and correlations of the studied variables. The results revealed that the correlation between social network and business performance was significant $(r=0.283, p<0.01)$.

Table 2: Means, standard deviations and correlations for the variables

\begin{tabular}{lllc}
\hline Study variables & Mean & Std. deviation & \multicolumn{2}{c}{ Correlation } \\
& & \multicolumn{2}{c}{$\mathbf{1}$} \\
\hline 1. Social network & 3.84 & 0.5 & \multicolumn{2}{c}{$.283^{* *}$} \\
2. Business performance & 3.78 & 0.48 & $.283^{* *}$ \\
\hline
\end{tabular}

$* \mathrm{p}<0.05$

$* * \mathrm{p}<0.01$

Table 3: Hierarchical regression analysis

\begin{tabular}{lll}
\hline Study variables & $\begin{array}{c}\text { Standardised Beta } \\
\text { First step }\end{array}$ & $\begin{array}{c}\text { Standardised Beta } \\
\text { Second step }\end{array}$ \\
\hline $\begin{array}{l}\text { Control variable } \\
\quad \text { Parental history }\end{array}$ & $-.218^{*}$ & $-.178^{*}$ \\
Independent variable & & \\
$\quad$ Social network & .218 & $.256^{*}$ \\
$\mathrm{R} \quad$ R2 & .047 & .333 \\
R2 change & .047 & .111 \\
F value & 4.029 & .064 \\
Significant F change & .048 & 5.005 \\
\hline
\end{tabular}

Hypothesis Testing: Table 3 summarises the result of the hierarchical regression analysis. In the first step, the model shows the $\mathrm{R}^{2}=.047, \mathrm{R}^{2}$ change $=.047, \mathrm{~F}$ value $=4.029$ and a significant $\mathrm{F}$ change of .048 which indicated that the model is significant. For the second step, the model was improved with $\mathrm{R}^{2}=.111$, $\mathrm{R}^{2}$ change $=.064, \mathrm{~F}$ value $=5.005$ and a significant $\mathrm{F}$ change $=.019$ which means that the model is also significant. Control variables were examined and parental history was included in the model as it achieved a valid significance level in both the first $(\beta=-.218, \mathrm{p}<.05)$ and second step $(\beta=-.178, \mathrm{p}<.01)$. However, the finding is inversely associated with business performance and against the view of previous research (Che Rose, Kumar and Yen, 2006). Meanwhile, the regression analysis revealed that social network was positively and significantly related with business performance $(\beta=.256, \mathrm{p}<0.05)$. Therefore, hypotheses 1 was supported. 
Discussion: The challenges facing by SME firms have led to a growing interest by scholars in entrepreneurship field including social network theme. Despite of the importance of social network, however there are limited studies done on social network especially for Malaysian SMEs scenario. Social network is important to SME firms as an important part of the firms' effectiveness and broadly accepted as a tool for securing resources from alters (Laere and Heene, 2003; Sengupta, 2011). This study revealed that business contact constitutes a big number in the Malay respondents' social network through name generator technique. This is followed by family members, friends and the least number is relatives. Previous literatures have widely discussed the important roles of business contact in enhancing entrepreneurs' business performance. For example, supplier plays a crucial role in supplying market and competitor information to the entrepreneur (Fortner, 2006; Idris, 2008). Millington, Eberhardt and Wilkinson (2006) also discussed the finding of foreign firms operating in China relied on their suppliers to provide information on the activities of their competitors. The information gleaned from the suppliers would be of purchasing activities of their competitors. If competitors cease to purchase certain items, this would be a reason to follow suit in their own business. The reason for these actions will be sought from other firms. In Malaysia, Hamed (1995) stated that Malay entrepreneurs depended on the information gleaned from their suppliers.

More than half of the successful manufacturing firms in Malaysia built social network consisting of family members and embraced the moral support, information and benefits gained (Osman and Hashim, 2003; Sulaiman and Mohd Saukani, 2007). This is supported by Birley (1985) whose study identified family members as an important player in the social network. Family members play an integral role in the success of entrepreneurs as these relationships are often close knit (Bratkovic and Antoncic, 2009). For the involvement of friends in the social network, the present study found that friends were at the third place. Ahmad (2005) found that some owner-managers in Malaysia depend heavily on friends for morale support and advice. Hamed (1995) also discovered that friends also provide funding to the entrepreneurs. Even though there is a lack of in-depth discussion of the roles of relatives in the social network, some studies have found that relatives provide great support to entrepreneurs (Bogren, Friedrichs, Rennemo and Widding, 2011; Copp and Ivy, 2001). Relatives comprise of a wider family network and also include the family of the spouses (Hamed, 1995). In this study, there is relatively small attention given to incorporate relatives in the social network. However, previous scholar for example Wahab (1996) discovered that the financial advisors of small business entrepreneurs in Malaysia comprised of relatives. Ahmad (2005) found that entrepreneurs in the tourism industry included relatives in their social network while Ibrahim (1998) also revealed that small-sized firms relied greatly on their relatives for financing since formal financing was often inaccessible. Among the reasons for sourcing financial aid from these informal channels are the ease of access, the urgency of financial need, the lack of formal procedures in obtaining funds and the flexibility in loan repayment.

Indeed, relying on social network alters are crucial to the SME entrepreneurs to gain important resources. Even though the government through their agencies provides the financial assistance for the SMEs' development, however, not all applicants are successful in securing the assistance. Omar (2006) brought forth the issue of the applicants' personalities in the selection process that could lead to bias especially for entrepreneurs who are not well or fully established. Abu Bakar (2008) reported that accessibility to financial aid is still very limited despite the government's efforts to promote the various aids programs. The author noted that graft and bureaucracy problems are among the significant factors that prevent certain entrepreneurs from getting assistance. This view is supported by Mohamed (2001) who noted that bureaucracy, slow decision making and grafting are synonymous with government agencies. Mohd. Jan, Wahab, Salleh, Abdul Kadir and Osman (2010) also found that bureaucracy is one of the factors that contributed to the failure of SMEs in Malaysia. In addition, Wahab (1996) also provided evidence that unreasonable levels of collateral and higher interest rates are among the barriers faced by small firms trying to gain access to financing. Another studies found that the collateral is taken into consideration by the financial institution prior to approving a loan to entrepreneurs (Mohd Harif, Hoe and Md. Zali, 2011; Zairani and Zaimah, 2013).

For the hypothesis testing, the hierarchical regression analysis was conducted to examine the relationship between social network and business performance. The result shows that social network is positively and significantly related to business performance. This finding supports past studies (Kristiansen, 2004; 
Ostgaard and Birley, 1996; Premaratne, 2001; Surin and Wahab, 2013; Thrikawala, 2011) on the importance of the alters to enhance business performance. Two new findings appear in this study regarding the relationship between social network and business performance that have not discovered in the literature so far. Firstly, the result of this study found that social network affect business performance where the business performance was measured by non-financial indicator. Prior studies tend to use financial data in measuring business performance. However due to constraint in gathering the financial data, the subjective measures were deemed appropriate especially for SMEs in Malaysia (Ahmad, 2007; Mahmood and Hanafi, 2013; Wahab, 1996). Secondly, social network affects business performance for Malay manufacturing start-up firms in Malaysia.

\section{Conclusion}

This study examined Malay manufacturing start-up firms in Malaysia with emphasis on the social network of these firms. It empirically tested the relationship between social networks with business performance while the business performance was measured by using non-financial indicator. Prior researchers have concentrated the social network research in the Western context; given the opportunities to carry out the research for this theme in the developing country like Malaysia. Besides, this paper also examined the roles of four types of alters in the entrepreneurs' social network; family members, friends, relatives and business contacts using the name generator technique. The result contributes to the growing body of knowledge especially on SME firm's use of social network in Malaysia. The finding shows that the social network is positively related to business performance. This study lies on the ties between entrepreneurs and their family members, friends, relatives and business contacts, making it a unique contribution to the literature centered on the social network theme. Previous literature on social network has focused on these ties but mainly in relation to the transferring of resources. Moreover, previous literature has been criticized as it overlooked the role of family members, friends, relatives and business contacts in social network and placed more focus on formal network. Lastly, previous research on SMEs in Malaysia have limited their scope to certain regions only (Muhammad, Ahmad and Shahnon, 2011; Zainol and Wan Daud, 2011). This study, however, includes all the regions in Malaysia and aims to generalize the findings to the whole manufacturing sector population.

It should be noted that this study has several limitations. The sectoral biases that are of concern in this study arise from the investigation concentrating SME manufacturing firms. The current study attempts to examine the social network for the following sectors; (1) textiles, apparels and leather (2) food and beverage (3) wood-based products (4) plastic-based products (5) rubber-based products and (6) electric and electronics. Therefore, the results produced might differ from that of other sectors. This study also focuses on start-up SME firms and as such, the results cannot be generalized to the manufacturing firms that are operating in the later phases. Lastly, the sample chosen is drawn from each region in Peninsular Malaysia and Borneo. To reach out to these respondents that are based over a wide area, a suitable data collection method, i.e. the postal questionnaire was adopted. This method is deemed suitable as opposed to the personal interview which involves higher cost and is time consuming. However, it is impossible to ensure that the selected respondents from each region are represented in the sample. To rectify this problem, the researcher sent reminder letters to the respondents four weeks after the original questionnaire was posted.

\section{References}

Abu Bakar, M. R. (2008). Tahap Kesampaian Bantuan Kewangan dan Kredit Kerajaan (BKKK) Terhadap Prestasi Perusahaan Kecil dan Sederhana (PKS) di Kedah. Unpublished Master's Dissertation. Universiti Sains Malaysia, Penang.

Ahmad, G. (2005). Small firm owner-managers' networks in tourism and hospitality. International Journal of Business and Society, 6(2), 37-54.

Ahmad, N. H. (2007). A Cross Cultural Study on Entrepreneurial Competencies and Entrepreneurial Success in SMEs in Australia and Malaysia. Doctoral Dissertation, University of Adelaide, Australia.

Birley, S. (1985). The Role of Networks in the Entrepreneurial Process. Journal of Business Venturing, 1(1), 107-117. 
Bogren, M., Friedrichs, Y. V., Rennemo, O. \& Widding, O. (2011). Networking Women Entrepreneurs-a Fruitful Base for Business Growth? Proceeding in International Council for Small Business (ICSB), Washington.

Boje, D. M. \& Whetten, D. A. (1981). Effects of Organizational Strategies and Contextual Constraints on Centrality and Attributions of Influence in Interorganizational Networks. Administrative Science Quarterly, 26(3), 378-395.

Borgatti, S. P. \& Foster, P. C. (2003). The Network Paradigm in Organizational Research: A Review and Typology. Journal of Management, 29(6), 991-1013.

Bratkovic, T. \& Antoncic, B. (2009). Networking of Copreneurs and Small Firm Growth: Personal Subnetworks Analysis. Zagreb International Review of Economics \& Business, 12(2), 33-56.

Brown, B. \& Butler, J. E. (1995). Competitors as Allies: A Study of Entrepreneurial Networks in the U.S. Wine Industry. Journal of Small Business Management, 33(3), 57-66.

Bruderl, J. \& Preisendorfer, P. (1998). Network Support and the Success of Newly Founded Business. Small Business Economics, 10(3), 213-225.

Cantner, U. \& Joel, K. (2011). Network Position, Absorptive Capacity and Firm Success. IUP Journal of Knowledge Management, 9(1), 57-83.

Che Rose, R., Kumar, N. \& Yen, L. L. (2006). Entrepreneurs success factors and escalation of small and medium-sized enterprises in Malaysia. Journal of Social Sciences, 2(3), 74-80.

Copp, C. B. \& Ivy, R. L. (2001). Networking trends of small tourism businesses in post-socialist Slovakia. Journal of Small Business Management, 39(4), 345-353.

Cromie, S. \& Birley, S. (1992). Networking by female business owners in Northern Ireland. Journal of Business Venturing, 7(3), 237-251.

Das, T. K. \& Teng, B. S. (1997). Time and Entrepreneurial Risk Behavior. Entrepreneurship: Theory \& Practice, 22(2), 69-88.

Fortner, M. L. (2006). Entrepreneurs and their Social Networks: Motivations, Expectations and Outcomes. Doctoral Dissertation, the George Washington University, United States.

Formbrun, C. J. (1982). Strategies for Network Research in Organizations. Academy of Management Review, $7(2), 280-291$.

Frazier, B. J. (2000). The Influence of Network Characteristics on Information Access, Marketing Competence and Perceptions of Performance in Small Rural Businesses. Doctoral Dissertation, Michigan State University.

Greve, A. (1995). Networks and Entrepreneurship - An Analysis of Social Relations, Occupational Background, and Use of Contacts during the Establishment Process. Scandinavian Journal of Management, 11(1), 124.

Greve, A. \& Salaff, J. W. (2003). Social networks and Entrepreneurship. Entrepreneurship: Theory \& Practice, 28(1), 1-22.

Hamed, A. B. (1995). The Personal Networks of Small Firm Entrepreneurs in Malaysia: An Exploratory Study. Doctoral Thesis, University of Glasgow.

Hansen, E. L. (1995). Entrepreneurial Networks and New Organization Growth. Entrepreneurship: Theory \& Practice, 19(4), 7-19.

Hoang, H. \& Antoncic, B. (2003). Network-based Research in Entrepreneurship: A Critical Review. Journal of Business Venturing, 18(2), 165-187.

Ibarra, H. (1993). Network Centrality, Power, and Innovation Involvement: Determinants of Technical and Administrative roles. Academy of Management Journal, 36(3), 471-501.

Ibarra, H. (1995). Race, Opportunity, and Diversity of Social Circles in Managerial Networks. Academy of Management Journal, 38(3), 673-703.

Ibrahim, M. D. (1998). Adoption of Project Appraisal Practice and Accessibility of Finance: An Empirical Analysis on Selected Small and Medium-sized Manufacturing Companies in Malaysia. Doctoral Thesis, University of Stirling.

Idris, A. (2008). Cultivating Innovation through Female Leadership: The Malaysian Perspective. Asian Social Science, 4(6), 1-10.

Jenssen, J. I. \& Koenig, H. F. (2002). The Effect of Social Networks on Resource Access and Business Start-ups. European Planning Studies, 10(8), 1039-1046. 
Kenny, B. \& Fahy, J. (2011). Network Resources and International Performance of High Tech SMEs. Journal of Small Business and Enterprise Development, 18(3), 529-555.

Kristiansen, S. (2004). Social Networks and Business Success. American Journal of Economics \& Sociology, 63(5), 1149-1171.

Laere, K. V. \& Heene, A. (2003). Social Networks as a Source of Competitive Advantage for the Firm. Journal of Workplace Learning, 15(6), 248-258.

Lee, F. H. \& Lee, F. Z. (2007). The Relationships between HRM Practices, Leadership Style, Competitive Strategy and Business Performance in Taiwanese Steel Industry. Proceedings of the 13th Asia Pacific Management Conference, Melbourne.

Lee, F. H., Lee, F. Z. \& Wu, W. Y. (2010). The Relationship between Human Resource Management Practices, Business Strategy and Firm Performance: Evidence from Steel Industry in Taiwan. The International Journal of Human Resource Management, 21(9), 1351-1372.

Liedka, R. V. (1991). Who do you know in the Group? Location of Organizations in Interpersonal Networks. Social Forces, 70(2), 455-474.

Mahmood, R. \& Hanafi, N. (2013). Learning Orientation and Business Performance of Women-owned SMEs in Malaysia: The Mediating Effect of Competitive Advantage. British Journal of Arts and Social Sciences, 11(II), 150-161.

Marsden, P. V. (1990). Network Data and Measurement. Annual Review of Sociology, 16, 435-463.

Martinez, M. A. \& Aldrich, H. E. (2011). Networking Strategies for Entrepreneurs: Balancing Cohesion and Diversity. International Journal of Entrepreneurial Behaviour \& Research in Organizational Behavior, 17(1), 7-38.

Millington, A., Eberhardt, M. \& Wilkinson, B. (2006). Guanxi and Supplier Search Mechanism in China. Human Relations, 59(4), 505-531.

Minai, M. S., Ibrahim, Y. \& Kheng, L. K. (2012). Entrepreneurial Network in Malaysia: Are there any Differences across Ethnic Groups? Journal of Business and Policy Research, 7(1), 178 - 192.

Mohd. Harif, M. A. A., Hoe, C. H. \& Md. Zali, S. K. (2011). Business financing for Malaysian SMEs: What are the banks' determining factors? World Review of Business Research, 1(3), 78-101.

Mohd. Jan, N., Wahab, I. A., Salleh, Z., Abdul Kadir, M. A. B. \& Osman, C. A. (2010). Study on Factors which Contribute to the Success and Failure of SMEs. Proceeding on National Conference on Entrepreneurship (NiCE), Shah Alam Convention Centre, Shah Alam, Selangor.

Muhammad, J., Ahmad, Z. \& Shahnon, S. (2011). SME Lending of the Northern Corridor Economic Region: Access and Needs. World Review of Business Research, 1(4), 18-32.

Ndubisi, N. O. \& Kahraman, C. (2005). Malaysian Women Entrepreneurs: Understanding the ICT Usage Behaviors and Drivers. Journal of Enterprise Information Management, 18(5/6), 721-739.

Nunnally, J. C. (1978). Psychometric Theory, New York: McGraw-Hill.

Nybakk, E., Lunnan, A., Jenssen, J. I. \& Crespel, P. (2013). The Importance of Social Networks in the Norwegian Firewood Industry. Biomass and Bioenergy, 57, 48-56.

Nybakk, E., Vennesland, B., Hansen, E. \& Lunnan, A. (2008). Networking, Innovation, and Performance in Norwegian Nature-based Tourism. Journal of Forest Products Business Research, 5(4), 1-26.

Omar, S. (2006). Malay Business. Revivalism through Entrepreneurship, Selangor: Pelanduk Publication.

Osman, I. \& Hashim, M. K. (2003). An Evaluation of the Business Practices in Malaysian SMEs Malaysian. Management Review, 38(2), 1-8.

Ostgaard, T. A. \& Birley, S. (1996). New Venture Growth and Personal Networks. Journal of Business Research, 36(1), 37-50.

Perry-Smith, J. E. (2006). Social Yet Creative: The Role of Social Relationships in Facilitating Individual Creativity. Academy of Management Journal, 49(1), 85-101.

Porras, S. T., Clegg, S. \& Crawford, J. (2004). Trust as Networking Knowledge: Precedents from Australia. Asia Pacific Journal of Management, 21(3), 345-363.

Premaratne, S. P. (2001). Networks, Resources, and Small Business Growth: The Experience in Sri Lanka. Journal of Small Business Management, 39(4), 363-371.

Quan, X. \& Motoyama, Y. (2010). Empirical Disaggregation of Social Networks: A Study of Ethnic Professional Associations and Entrepreneurship in Silicon Valley. Journal of Small Business and Entrepreneurship, 23(4), 509-526. 
Reese, P. R. (1992). Entrepreneurial Networks and Resource Acquisition: Does Gender make a Difference? Doctoral Dissertation, The University of North Carolina.

Rowley, T. J. (1997). Moving beyond dyadic ties: A network theory of stakeholder influences. The Academy of Management Review, 22(4), 887-910.

Sengupta, A. (2011). Network Strategy and Access to Business Finance: Indian Entrepreneurs in the Information and Communication Technology Industry. Journal of Entrepreneurship, 20(1), 103-126.

Starr, J. A. \& MacMillan, I. C. (1990). Resource Cooptation via Social Contracting: Resource Acquisition Strategies for New Ventures. Strategic Management Journal, 11, 79-92.

Sulaiman, N. \& Mohd. Saukani, M. N. (2007). Modal Sosial dalam Mempertingkat Daya Saing Firma Perusahaan Kecil dan Sederhana (PKS). International Journal of Management Studies, 14(2), 93-111.

Surin, E. F. \& Wahab, I. A. (2013). The Effect of Social Network on Business Performance in Established Manufacturing Small and Medium Enterprises (SMEs) in Malaysia. Proceeding in 4th International Conference on Business, Economics and Tourism Management 2013, South Korea.

Thrikawala, S. S. (2011). Impact of Strategic Networks for the Success of SMEs in Sri Lanka. World Journal of Social Sciences, 1(2), 108 - 119.

Tsai, W. (2001). Knowledge Transfer in Intraorganizational Networks: Effects of Network Position and Absorptive Capacity on Business Unit Innovation and Performance. Academy of Management Journal, 44(5), 996-1004.

Wahab, I. A. (1996). Financing the Growth of Small Manufacturing Firms in Developed and Developing countries: A Comparative Study of United Kingdom and Malaysia. Doctoral Thesis, Loughborough University, Leicester.

Witt, P. (2004). Entrepreneurs' Networks and the Success of Start-ups. Entrepreneurship \& Regional Development, 16(5), 391-412.

Witt, P., Schroeter, A. \& Merz, C. (2008). Entrepreneurial Resource Acquisition via Personal Networks: an Empirical Study of German Start-ups. Service Industries Journal, 28(7/8), 953-971.

Zainol, F. A. \& Wan Daud, W. N. (2011). Indigenous ("Bumiputera") Malay Entrepreneurs in Malaysia: Government Supports, Entrepreneurial Orientation and Firms Performances. International Business and Management, 2(1), 86-99.

Zairani, Z. \& Zaimah, Z. A. (2013). Difficulties in Securing Funding from Bank: Success Factors for Small and Medium Enterprises (SMEs). Journal of Advance Management Science, 1(4), 354-357.

Zimmerman, M., Barsky, D. \& Brouthers, K. (2009). Networks, SMEs, and International Diversification. Multinational Business Review, 17(4), 143-162. 